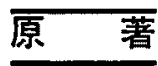

\title{
抗結核薬の喀痰中濃度にかんする研究
}

\author{
能本大学医学部第一内科学教窒（指遵 徳臣晴比古教授 河盛勇造前教授） \\ 野 津 手 晴 男

\section{STUDIES ON THE CONCENTRATION OF ANTITUBERCULOSIS DRUGS IN SPUTUM}

Haruo NotsuTE

The First Department of Internal Medicine

Kumamoto University School of Medicine

(Director: Prof. Haruhiko Tokuomi, ex-Prof. Yuzo Kawamori)

\begin{abstract}
概要 各種抗結核薬の病巣内への渗透を推定するために, 喀疢中および臟器内濃度を測定し, あわせ て血中濃度との関係を比較検討した，ethambutolの喀疢中濃度は高値を示し，血中濃度と，ほふ同等 の値であり,かつ長時間持続した，capreomycinの揢疢中濃度は血中濃度に比し低値で, 経時的に漸減 する傾向にあつたが, kanamycinおよびstreptomycinよりも高濃度の值を示す例が多かつた， ethionamide拉よび $\alpha$-propylthioiso-nicotinamideの喀痰中濃度はほとんどの症例で測定不能の低值を示した。 また， E B , KM, S Mの喀疢中濃度と喀痰中結核菌の推移扎よひ耐性出現状況とを比較すると，喀疢 中濃度が高いものに結核菌の陰性化あるいは耐性獲得が速い傾向が認められた。
\end{abstract}

\section{第 1 章 緒 言}

一般に化学療法を行ならにあたつて, 薬物の投 与方法执よび量を決定するためには，まずその吸 収，体内分布および排泄が解明され极ばならな い. 結核の化学療法に扎いても同様であつて抗結 核涾の病巣内結核菌に対する作用を考えるには病 巣内薬物濃度を知る必要があると思う。しかしこ の状況を明らかにするには切除病巣について検討 する以外確実な方法がないので，一般には血中濃 度の高さおよびその時間的推移によつて推定して いるにすぎない。これに対して肺結核の場合もし 病巣より喀出される喀痰中の薬物濃度を測定する ならば，病巣内薬物濃度を知るためによりよい手 ががりになると考えられ臨床的にも有意義と思わ れる.

本論文の一部は第13回日本化学㙩法学会総会、第 8 回日本化学潧法学会西日本支部総会, 第41回日本 結核病学会総会㧍よび第19回結核病学会九州地方会 総会において登表した。
河村2) は I NHについて喀痰中濃度を測定し報 告しているが，わたくしは主として二次抗結核薬 kanamycin (KM), ethionamide(1314TH), ethambutol (EB), capreomycin (CPM) などについ て咯痰中濃度を定量し各薬物の肺内移行を比較検 討したので以下その成績を報告する。

\section{第 2 章 実験方法}

1）採痰：前日より化学療法薬を全て中止 乙， E B は検查当日早朝空腹時に $25 \mathrm{mg} / \mathrm{kg}$ を経口 投与した後直ちに含濑させ， $1 ， 3 ， 5 ， 7$ ， $9 ， 11 ， 13 ， 15$ 時間後に蓄痰，C P M は早朝 $1 \mathrm{~g}$ 筋肉内注射 ᄂ, $1 ， 3 ， 5 ， 7 ， 9$ 時間後火蓄 痰，KM扰よびstreptomycin (SM) は早朝各 1 $\mathrm{g}$ 筋肉内注射乙，1，5，9時間後炕蓄痰，1314 T Hおよび $\alpha$-propylthioiso-nicotinamide (1321 T $\mathrm{H} ）$ は朝食後各 $0.5 \mathrm{~g}$ 経口投与し，1，4，8， 12時間後に分割蓄痰した。

2）採血：E B は投与後 1，4，8時間目に 採血，C P M は投与後 1，2，4，8时間目に採 
血，1314THおよび1321 T Hについては 4 時間目 に採血し，分離した血清を被検試料とした。

3）咯痰の前処理：薬物の喀痰中濃度を生物 学的に定量するには, 喀痰の均質化拉よび雑菌処 理が必要であり，このために河盛》の方法に準じ てパパイン液を用いた。すなわちシャーレ中に蓄 痰された喀痰から 5〜 7 mlを滅菌スピッツグラ スに取り，5\%パハイン液を $1 / 10$ 量添加し，充分 に擋挥した後, $45^{\circ} \mathrm{C}$ 水槽中にて 30 分間消化し, さらに沸騰水中で15分間加温後遠心沈殿を行な い，上清を被検試料とした。

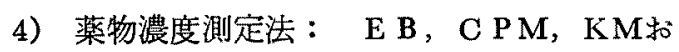
よび S Mの喀痰中抢よび血中濃度については金 沢3)が I N H濃度測定に用いた非病原性抗酸菌H7 株を指示菌とする寒天平板拡散法を用いた。す なわち $1.5 \%$ Kirchner寒天培地（10\%アルブミン

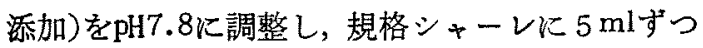
分注して薄層平板培地を作る。小川培地に発育し た金沢裕博士より分与されたH- 7 株の 1 白金耳を Dubos培地 $5 \mathrm{ml}$ に16 24時間培養し，上層菌液を $0.5 \%$ に稀釈して 平板培地表面に $2 \mathrm{ml}$ 接種した。 接種後直ちに余剰菌液を吸引除去し，その培地表 面にカップを立て，カップ内に被検試料を入れ 2 日間培盖した後出現した発育阻止円を測定した。 すでにE B 血中濃度の測定法としてこの方法が

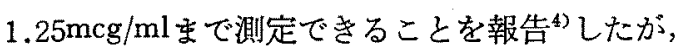
その後 $0.625 \mathrm{mcg} / \mathrm{ml}$ ま 測定可能な感受性の高 い覀株をH-7 原株より分離して指示菌とした. 1314T H和よび1321 T Hの喀疢中および血中濃度 の測定は $2.5 \%$ Kirchner寒天培地（10\%馬血清添 加）をpH 6.6〜 6.8 調整して，小川式曲り試験 管に $5 \mathrm{ml}$ ずつ分注し， $\mathrm{H}_{37} \mathrm{RV}$ 株を指示菌とする直 立拡散法卓を用いた。

\section{第 3 章 実験成績}

実験 1 . 寒天平板拡散法および直立拡散法によ る各薬物の喀痰中濃度測定法の吟味。

E B は40，20，10，5，2.5，1.25，0.625 $\mathrm{mcg} / \mathrm{ml}$ まで 7 段階，C P Mは50，25, 12.5, 6.25， $3.125 \mathrm{mcg} / \mathrm{ml} て ゙ 5$ 段階，KMは40，20，10，

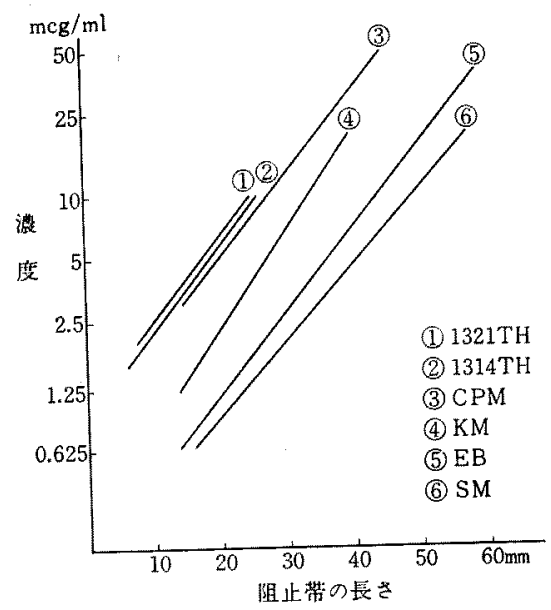

㘠 1，各菜物の標準曲線

$5 ， 2.5,1.25 \mathrm{mcg} / \mathrm{ml}$ まで 6 段階, $\mathrm{S} \mathrm{M} 20$ ，

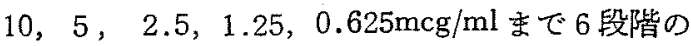
既知濃度添加喀痰について寒天平板払散法による 阻止円の大きさを直径 2 方向より測定し，その平 均值をとつた。 $1314 \mathrm{~T}$ H抢よび1321 T Hは10，5

$2.5 ， 2 ， 1.5 \mathrm{mcg} / \mathrm{ml}$ まで 5 段階の既知濃度添 加喀痰について直立拡散法を行ない阻止帯の長さ を測定した。結果は図 1 のごとく，片対数方眼紙 に阻止带の長さを整数目盛に, 既知薬物添加濃度 を対数目盛にとると直線関係を示し， E B， C P M, KM, S M, 1314T H和よび1321 T Hの喀痰中 濃度の测定法として使用しうることを確認した。

薬物の揢痰中濃度を生物学的に測定する場合, 喀痰処理過程に衫汀るパパイン液による消化括上 び加熱処理により，薬物の力価の低下が考光られ るので，本実験に使用した 6 種類の薬物につい て，処理前の愘痰に上記と同じ既知濃度の薬物を 加え, 喀痰処理と同過程によつて, 加温, 加熱し た系列と，パパイン液消化および加熱処理を加党 た喀痰に同じ既知濃度の薬物を加えた系列の 2 系 列を作製し，おの括のの阻止円の大きさを検討し たが，結果は 2 系列ともに図1に示すごとくであ り，喀痰処理による各薬物の力洒の低下は無視し らることがわかつた。

実験 2 . E B 喀痰中濃度

肺結核36例，慢性気管支炎 7 例の計43例につい 
表 1. E B 25mg/kg投与後の略痰中恬よび血中䬶度の経時的推移 $(\mathrm{mcg} / \mathrm{ml})$

\begin{tabular}{|c|c|c|c|c|c|c|c|c|c|c|c|c|c|c|}
\hline \multirow{2}{*}{ 症. } & \multirow{2}{*}{ 例 } & \multirow{2}{*}{$\begin{array}{l}\text { 瘦名 } \\
\text { 病型 }\end{array}$} & \multicolumn{2}{|r|}{ 㮫 } & \multicolumn{2}{|c|}{ 疹 } & 中 & \multicolumn{2}{|c|}{ 濃 } & \multicolumn{2}{|l|}{ 度 } & \multicolumn{3}{|c|}{ 血中浱度 } \\
\hline & & & 役与前 & $\begin{array}{c}\text { 時間 } \\
0 \sim 1\end{array}$ & $1-3$ & $3-5$ & $5-7$ & $7 \sim 9$ & $9-11$ & $11-13$ & $13 \sim 15$ & 1 時間 & $4 "$ & $8 n$ \\
\hline 1. $\widehat{\delta} 45$ & $43 \mathrm{~kg}$ & $\mathrm{C}_{2} \mathrm{Ky}_{1}$ & 0 & 0 & 2.2 & 2.7 & 1.4 & 0.7 & 1.3 & & & 1.1 & 7.6 & \\
\hline 2. 今 43 & 62 & $\mathrm{C}_{3} \mathrm{Kz}$ & 0 & 0 & 2.5 & 2.2 & 2.1 & 0.8 & - & & & 2.0 & 4.1 & \\
\hline 3.847 & 52 & $\mathrm{C}_{2} \mathrm{Ky}_{3}$ & 0 & & 0.7 & 1.9 & 1.9 & 2.1 & 1.6 & & & 0.9 & 2.0 & \\
\hline 4. 1876 & 50 & $\mathrm{C}_{3} \mathrm{Kx}_{2}$ & 0 & 0 & 1.9 & 2.2 & 3.1 & 1.8 & 3.6 & & & 1.5 & 2.2 & \\
\hline $5 . \delta 58$ & 60 & $\mathrm{C}_{2} \mathrm{Kz}$ & 0 & & 5.0 & 2.1 & 3.7 & 2.1 & 1.9 & 2.3 & 2.1 & 2.7 & 3.2 & 1.2 \\
\hline 6. 우30 & 50 & 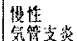 & 0 & 1.4 & 1.8 & 2.2 & 3.5 & 2.7 & 2.7 & 3.8 & 3.3 & 2.0 & 2.2 & 0 \\
\hline 7.845 & 47 & H & 0 & 0 & 3.5 & 0.8 & 3.0 & 5.0 & - & 2.1 & & 0 & 2.2 & 1.5 \\
\hline
\end{tabular}

て愘疢中 E B濃度を測定した。

喀痰中 E B 濃度を測定するにあたつて，E B 錠 斉投与による口腔内での $\mathrm{E} \mathrm{B}$ 混入を考慮して， E B投与直後充分な含嗽を行なわせ，その直後と 1 時間後の唾液中 $\mathrm{E} \mathrm{B}$ 濃度を 5 例について測定した が，測定しえない程の低濃度であつた。しかし被 検症例では充分な含嗽が行なわれないことも考壳 カプセルを使用し，錠剤の喀痰中濃度と比較検討 した。カプセル使用例では $0 \sim 1$ 時間蓄疢の E B 濃度は最高 $1.3 \mathrm{mcg} / \mathrm{ml}$ であり，8例中 6 例は阻 止円の出現をみなかつた。これに対して錠剤使用 例では $0 \sim 1$ 時間の蓄痰で， $0 \sim 31 \mathrm{mcg} / \mathrm{ml}$ まて広 範囲のばらつきを示した。このことから錠剤使用 例の喀痰中濃度は口腔内での E B 混入の可能性が 考えられるので，本実験ではカプセルを使用し た.

E B の喀疢中濃度と血中濃度の経時的推移を 7 例について検討すると表 1 に示すごとく，喀痰中 濃度では投与前に全例発育阻止円を認めず，0〜 1 時間蓄痰では 1 例のみに $1.4 \mathrm{mcg} / \mathrm{ml}$ 示した にすぎないが，1時間以後の蓄痰では全例測定可 能の値を示し, 平均值で $1 \sim 3$ 時間 $2.51 \mathrm{mcg} / \mathrm{ml}$, $3 \sim 5$ 時間 $2.01 \mathrm{mcg} / \mathrm{ml}, 5 \sim 7$ 時間 $2.67 \mathrm{mcg} / \mathrm{ml}$, $7 \sim 9$ 時間 $2.17 \mathrm{mcg} / \mathrm{ml}, 9 \sim 11$ 時間 $2.22 \mathrm{mcg} / \mathrm{ml}$ あり，13〜15時間蓄痰について検討した 2 例でも $3.3 ， 2.1 \mathrm{mcg} / \mathrm{ml}$ を示した.これに反して血中濃 度は 1 時間值が $0 \sim 2.7 \mathrm{mcg} / \mathrm{ml}$, 平均 $1.73 \mathrm{mcg} / \mathrm{ml}$, 4 時間值 $2.0 \sim 7.6 \mathrm{mcg} / \mathrm{ml}$ ，平均 $3.35 \mathrm{mcg} / \mathrm{ml}, 8$ 時間では $0,1.2,1.5 \mathrm{mcg} / \mathrm{ml}$ であり， 4 時間值

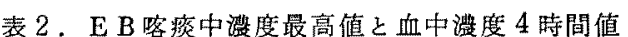

\begin{tabular}{|c|c|c|c|c|c|}
\hline & 血 & 中 & 漍 & 度 & \\
\hline \multirow{5}{*}{$\begin{array}{l}\text { 喀 } \\
\text { 茨 } \\
\text { 中 } \\
\text { 漫 } \\
\text { 度 }\end{array}$} & & $<2.5 \mathrm{mcg} / \mathrm{ml}$ & $2.5 \sim 4.9$ & $\geq 5.0$ & 部 \\
\hline & $<2.5 \mathrm{mcg} / \mathrm{ml}$ & 6 & 1 & 1 & 8 \\
\hline & $2.5 \sim 4.9$ & 9 & 6 & 6 & 21 \\
\hline & $\geq 5.0$ & 1 & 3 & 3 & 7 \\
\hline & 諦 & 16 & 10 & 10 & 36 \\
\hline
\end{tabular}

が最高を示した。すなわち $\mathrm{E} \mathbf{B}$ の揢痰中濃度は経 時的濃度の差が血中程著明ではなく，両者の間に 相関を見出すことはできなかつた。

そこで血中濃度 4 時間值と投与 1 時間以後 2 時 間ごとに15時間まで分割採取した蓄痰の喀痰中濃 度の最高値を36例について比較すると，表2のご とく愘痰中濃度が高值を示すの20例，低值を示 すもの 15 例で，喀痰中濃度は $2.5 \mathrm{mcg} / \mathrm{ml}$ 以上を 示す症例が 28 例 $(76 \%)$ もあり，最高 $9.3 \mathrm{mcg} / \mathrm{ml}$ で平均値 $3.7 \mathrm{mcg} / \mathrm{ml}$ であつた。これに 対して 4 時間目の血中濃度は $1 \sim 10 \mathrm{mcg} / \mathrm{ml}$ 範因内にあ り, 平均值 $3.8 \mathrm{mcg} / \mathrm{ml}$ 示した。すなわち喀痰 中濃度は血中濃度とほぼ同じ值を示し，E B が喀 痰中に高濃度に排泄されることは明らかである が，個々の症例では血中濃度が高值を示するの 程，喀痰中濃度も高值を示すといつた関倸は認め 難い成績であつた。

次いで喀痰の性状括よび量と濃度との関係を検 討した，粘液性喀痰19例，膿性喀痰12例の濃度の 平均值は膿性 $3.64 \mathrm{mcg} / \mathrm{ml}$, 粘液性 $3.46 \mathrm{mcg} / \mathrm{ml}$ であ り，注とんど差はなかつた。また喀痰量に伴なう 濃度の変化も認めえなかつた。 
表 3. E B 25mg $/ \mathrm{kg}$ 投与後の切除肺に扣けるE B 签 度 $(\mathrm{mcg} / \mathrm{g})$

\begin{tabular}{|c|c|c|c|c|c|c|}
\hline $\begin{array}{l}\text { 投 } \\
\text { 与. } \\
\text { 法 }\end{array}$ & 症 & 例 & 健康部 & 空洞壁 & 空洞内 & $\begin{array}{l}\text { 術 直前 } \\
\text { 血中港度 }\end{array}$ \\
\hline \multirow{3}{*}{$\begin{array}{c}3 \\
\text { 日 } \\
\text { 間 } \\
\text { 投 } \\
\text { 年 }\end{array}$} & 1. 우 400 & $-45 \mathrm{~kg}$ & 2.5 & 1.6 & \multirow[t]{3}{*}{$<0,6$} & \multirow{3}{*}{$\begin{array}{l}1.6 \\
2.1\end{array}$} \\
\hline & 2. 占 28 & 56 & 3.8 & 3.4 & & \\
\hline & $3 . శ 46$ & 52 & 6.8 & 2.6 & & \\
\hline \multirow{3}{*}{$\begin{array}{c}\text { 当 } \\
\text { 投 } \\
\text { 学 }\end{array}$} & 1. 936 & 44 & 4.4 & 1.9 & \multirow[t]{3}{*}{$<0.6$} & \\
\hline & 2. 含 42 & 60 & 1.9 & 1.9 & & \\
\hline & 3.350 & 55 & 8.2 & 3.0 & & \\
\hline
\end{tabular}

実戨 3 ．切除肺扣よび切除腎におけるEＢの組 織内濃度

切除手術を受ける肺結核患者 6 例のうち， 3 例 に対しては術前2 日前より術日まで 3 日間E B 25 $\mathrm{mg} / \mathrm{kg}$ を 1 日 1 回早朝空腹時に投与し，術直前の 血中濃度を測定し，他の 3 例には術前麻酔導入直 前に E B 25mg/kgを 1 回投与した. 切除蔵器はでき る限り血液の混入を避けるために圧縮を加え，無 菌的にホモジナイザーで磨砕し，乳剤として被検 試料とした，成績は表 3 に示すごとく 3 日間連続 投与した症例の術直前の血中濃度は $1.6 \mathrm{mcg} / \mathrm{ml}$, $2.1 \mathrm{mcg} / \mathrm{ml}$ であつたのに 健康部では $2.5 \sim 6.8$ $\mathrm{mcg} / \mathrm{g}$ 高值であり,空洞壁でも $1.6 \sim 3.4 \mathrm{mcg} / \mathrm{g}$ であつた。これに対し空洞内では $0.625 \mathrm{mcg} / \mathrm{g}$ 以 下の低值を示した。術前 1 回投与例でも健康部が 高く，次いで空洞壁で，空洞内では測定不能の低 值であつた。

腎結核 3 例，水腎症 2 例計 5 例の患者に E B 25 $\mathrm{mg} / \mathrm{kg}$ 早朝空腹時に 1 日 1 回宛 3 日間連続投与 後切除した腎について，切除肺と同様にして組織 内E B濃度を測定した。成績は表 4 のごとく健康

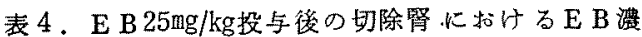
度 $(\mathrm{mcg} / \mathrm{g})$

\begin{tabular}{|c|c|c|c|c|c|}
\hline 症 & 例 & 病 名 & 健康部 & 空洞壁 & 空洞内 \\
\hline 1. 우22才 & $52 \mathrm{~kg}$ & 結 核 & 9.5 & 4.3 & 1.1 \\
\hline 2. 우19 & 46 & " & 5.7 & 2.7 & 0.6 \\
\hline 3. ิิ 28 & 55 & $"$ & 4.0 & & \\
\hline 4. 1333 & 46 & 水荋症 & 10.7 & & \\
\hline 5. 우64 & 40. & "r & 2.5 & & \\
\hline
\end{tabular}

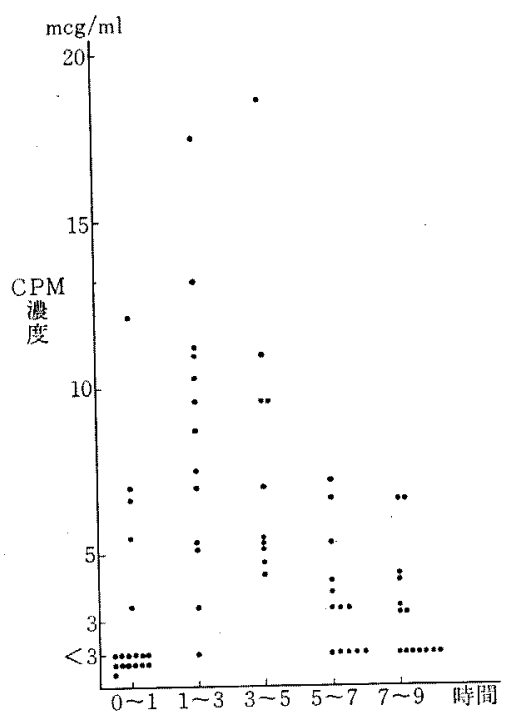

図 2、落痰中C PM涭度の経時的推移

部 $2.5 \sim 10.7 \mathrm{mcg} / \mathrm{g}$, 空洞壁 $2.7,4.3 \mathrm{mcg} / \mathrm{g}$, 空洞

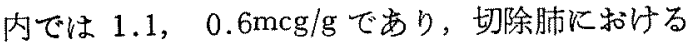
と同粎空洞内 E B 濃度は健康部, 空洞壁に比し低 值であつた。

\section{奉験 4。CPMの喀痰中濃度}

肺結核患者51例江 C P M $1 \mathrm{~g}$ 筋注し, 喀痰中 C P M濃度を測定した。喀痰を経時的に分割採取 し喀痰中C P M濃度の推移をみると, 図 2 亿示す ごとく 0 〜時間の蓄痰では18例中13例が $3 \mathrm{mcg} /$ ml以下であるが， 1 3 時間の蓄痰では 13例中 12 例が $3 \mathrm{mcg} / \mathrm{ml}$ 以上にあり，最高值 $17.5 \mathrm{mcg} / \mathrm{ml}$ を示し, $3 \sim 5$ 時間では全例 $3 \mathrm{mcg} / \mathrm{ml}$ 以上で最高 $18.6 \mathrm{mcg} / \mathrm{ml}, 5 \sim 7$ 時間では13例中 $3 \mathrm{mcg} / \mathrm{ml}$ 以上 のもの 8 例, $7 \sim 9$ 時間の蓄痰では 14 例中 7 例が $3 \mathrm{mcg} / \mathrm{ml}$ 以上で最高 $6.6 \mathrm{mcg} / \mathrm{ml}$ にすぎなかつ た.

血中C P M濃度は図 3 のごとく 1 時間值が最も 高く最高 $64 \mathrm{mcg} / \mathrm{ml}$, 最低 $28 \mathrm{mcg} / \mathrm{ml}$ であり, 平均值 は 1 時間值 $43.4 \mathrm{mcg} / \mathrm{ml}, 2$ 時間值 $33.6 \mathrm{mcg} / \mathrm{ml}, 4$ 時間值 $20.2 \mathrm{mcg} / \mathrm{ml}, 8$ 時間值 $13.0 \mathrm{mcg} / \mathrm{ml}$ であつ た。すなわち血中濃度は 1 時間值が最高を示し， 喀痰中濃度は $1 \sim 5$ 時間值が最高であり, 時間の 経過ととるに低下している，また血中濃度 1 時間 


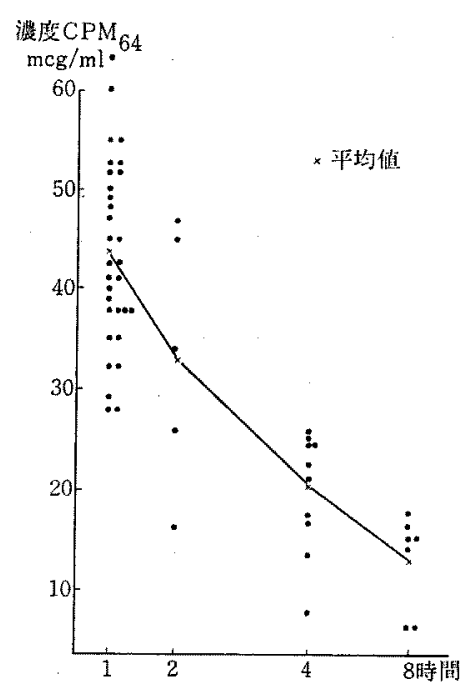

因 3．ＣPM1 g 投与後の血中漊度

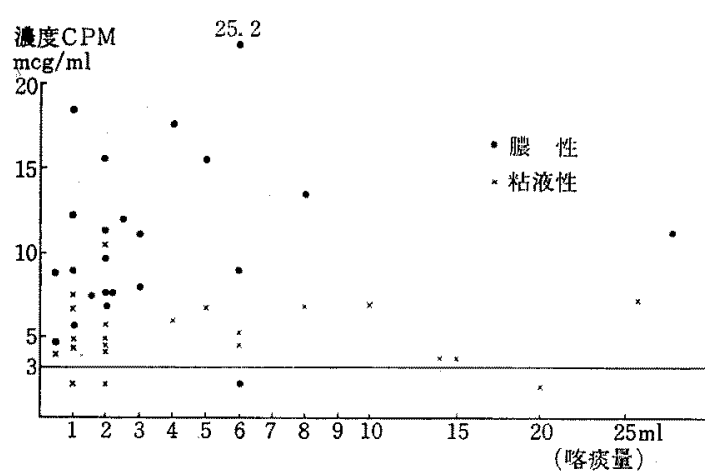

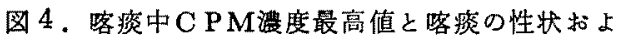
び量との関倸

值と分割採取した喀痰の最高值とを30例について 比較すると，喀痰中濃度は測定不能の低值たつた 2 例を含み最高值 $18.3 \mathrm{mcg} / \mathrm{ml}$, 平均値 $8.38 \mathrm{mcg} / \mathrm{ml}$ であり，血中濃度 1 時間值に比し低濃度であり， かつ両者の相関性は認められなかつた。

喀痰量および性状と濃度との関係を検討すると 図 4 のごとく，喀痰量の変化に伴なら濃度の変化 は認められなかつたが，喀痰の性状と喀痰中濃度 の最高値を比較すると，膿珄喀痰では22例中測定 不能は 1 例のみで, 最高 $25.3 \mathrm{mcg} / \mathrm{ml}$, 平均値 11.1 $\mathrm{mcg} / \mathrm{ml}$ であるのに対し，粘液性喀痰では23例中
3 例が $3 \mathrm{mcg} / \mathrm{ml}$ 以下であり, 最高 $17.6 \mathrm{mcg} / \mathrm{ml}$,平 均值 $5.5 \mathrm{mcg} / \mathrm{ml}$ であり, 膿性喀痰が粘液性喀痰よ り高濃度の值を示した。さらに喀痰の性状と濃度 との関係を $1 \sim 9$ 時間蓄痰した51例について検討 したところ，平均值で膿性喀痰 $7.9 \mathrm{mcg} / \mathrm{ml}$, 粘液 性喀疢 $6.8 \mathrm{mcg} / \mathrm{ml}$ であり, 最高值の比較の場合と 同様に膿性喀痰が高濃度を示す傾向がみられた。

実験 5，C PM，KMおでび SMの喀痰中濃度 の比較

肺結核患者48例を対象とし，C P M，KM和よ び SMを各 $1 \mathrm{~g}$ 宛投与し，各薬物の喀痰中濃度を 比較検討した。

まず同一症例に同一薬物を 3 日間連続投与し， 毎日薬物投与後 $1 \sim 5$ 時間蓄痰させ，その薬物の

表 5. CPM, KM \& SM各 $1 \mathrm{~g}$ 連日 3 日間投与後 の喀痰中漊度 $(\mathrm{mcg} / \mathrm{ml})$

\begin{tabular}{|c|c|c|c|c|c|c|}
\hline & 症 & 例 & 学研病型 & 1 日目 & 2 日目 & 3 日目 \\
\hline \multirow{3}{*}{ CPM } & 우38才 & $45 \mathrm{~kg}$ & $\mathrm{C}_{3} \mathrm{Ky}_{2}$ & 3.5 & 3.3 & 3.3 \\
\hline & $\S 35$ & 53 & $\mathrm{C}_{2} \mathrm{Kz}$ & 6.2 & 6.4 & 6.8 \\
\hline & 우 26 & 40 & $\mathrm{C}_{2} \mathrm{Kz}$ & 3.8 & 4.0 & 3.8 \\
\hline \multirow{3}{*}{$\mathrm{KM}$} & \$ 34 & 56 & $\mathrm{~F}$ & 3.0 & 2.8 & 3.5 \\
\hline & $\$ 66$ & 50 & $\mathrm{~F}$ & 5.9 & 6.3 & 6.0 \\
\hline & 우43 & 42 & $\mathrm{C}_{2} \mathrm{Kz}$ & 4.4 & 3.9 & - \\
\hline \multirow{3}{*}{$S M$} & $\$ 46$ & 48 & $F$ & 4.6 & 5.0 & 5.2 \\
\hline & 우70 & 38 & $\mathrm{~F}$ & 3.6 & 3.6 & 4.0 \\
\hline & $\S 42$ & 49 & $\mathrm{C}_{2} \mathrm{Ky}_{2}$ & 1.4 & 1.1 & 1.4 \\
\hline
\end{tabular}

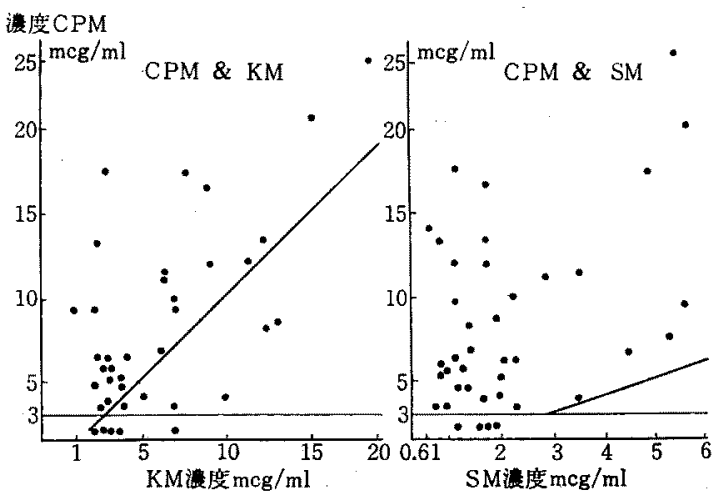

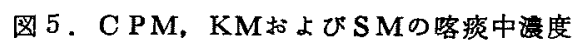


喀资中濃度を測定した。結果は表 5 のごとく， C PM，KM括よび S M とる同一症例では 3 日間 濃度の変動はみられなかつた。

C P M と KM， C PMと SMとの喀痰中濃度の 比較は図 5 に示すと括りで，CPMとKMを38例 について比較するとC P Mが高値のもの27例で， 最高 $25.3 \mathrm{mcg} / \mathrm{ml}$, 平均值 $9.1 \mathrm{mcg} / \mathrm{ml}, \mathrm{KM}$ では最 高 $19.8 \mathrm{mcg} / \mathrm{ml}$, 平均值 $5.6 \mathrm{mcg} / \mathrm{ml}$ であり, C P M が高值を示す例が多かつた，C P MとSMを40例 について比較すると C P M が高値を示するの36例 90\%であり，SMでは汪とんどの症例に和いてそ の喀痰中濃度は C P M K比し低值であり, 最高 $5.7 \mathrm{mcg} / \mathrm{ml}$,平均値 $2.3 \mathrm{mcg} / \mathrm{ml}$ であつた。

C P Mの喀痰中濃度は膿性喀痰が粘液性喀痰よ り高值を示す例が多いことは前述したが，KMお でびS Mについても喀痰性状と濃度との関係を検 討した。結果は図 6 に示すごとく，KMKあつて は膿性喀疢の最高 $19.8 \mathrm{mcg} / \mathrm{ml}$, 平均值 $8.4 \mathrm{mcg} / \mathrm{ml}$, 粘液性喀痰の最高 $12.0 \mathrm{mcg} / \mathrm{ml}$, 平均值 $3.8 \mathrm{mcg} / \mathrm{ml}$ であり，SMでは膿性喀痰の最高 $5.7 \mathrm{mcg} / \mathrm{ml}$, 平 均值 $3.2 \mathrm{mcg} / \mathrm{ml}$, 粘液性喀痰, 最高 $3.9 \mathrm{mcg} / \mathrm{ml}$, 平 均值 $1.5 \mathrm{mcg} / \mathrm{ml}$ であつた。すなわち $\mathrm{KM} ， \mathrm{~S} \mathrm{M}$ とも膿性喀痰の場合が高濃度の值を示す例が多か つた。

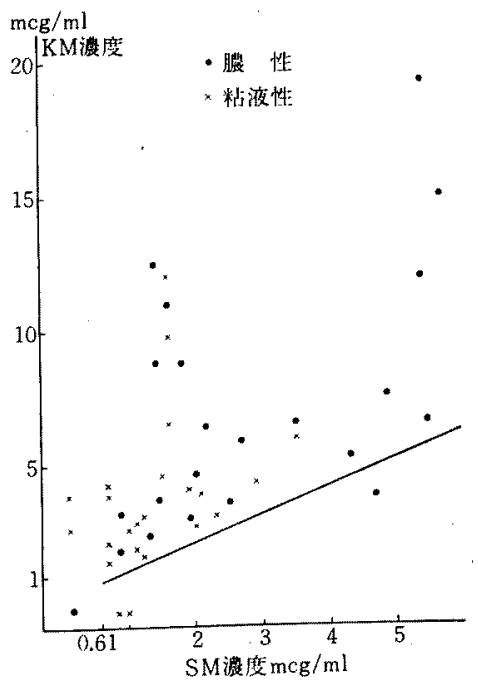

図 $6 . \mathrm{KM} \& \mathrm{SM}$ の喀痰中濃度と喀痰性状との関係
表 $6.1314 \mathrm{TH} 0.5 \mathrm{~g}$ 投与後の略痰中および血中 濃度 $(\mathrm{mcg} / \mathrm{ml})$.

\begin{tabular}{|c|c|c|c|c|}
\hline \multirow{2}{*}{ 烓击 例 } & \multicolumn{3}{|c|}{ 喀祯 } & \multirow{2}{*}{$\begin{array}{l}\text { 血中浱度 } \\
\text { (4時間值) }\end{array}$} \\
\hline & 0 ～4時間 & $4-8$ 時間 & $8-12$ 時間 & \\
\hline 1. $345 才$ & 0 & 1.5 & 0 & 2.0 \\
\hline 2. 우30 & 1.8 & 0 & 3.0 & 2.0 \\
\hline 3. 우58 & 1.8 & 1.6 & 0 & 0 \\
\hline 4. 含 36 & 2.7 & - & - & 2.7 \\
\hline $5 . \hat{\delta} 40$ & 1.7 & 2.5 & 0 & 0 \\
\hline $6 . \widehat{\delta} 49$ & 0 & 2.6 & 0 & 8.0 \\
\hline
\end{tabular}

以上のごとく個々の症例を比較すると 3 薬の愘 痰中濃度は区々であるが，一般にC P Mが最高值 を示し，KMがこれに次ぎ， SMが最低を示す症 例が多い成績であつた。

実験 6.1314 T Hお゙ひび1321 THの愘疢中濃度 肺結核患者に1314 T Hおよび1321 T H 0.5 g 投 与後の喀痰中および血中濃度を測定した。

血中濃度 4 時間値は両薬とも低值ではあるが， ほとんどの症例に測定可能であつた。一方喀痰中 濃度は1314 T Hでは表 6 に示すごとく阻止帯を示 したものは26例中 6 例に過ぎず，最高 $3 \mathrm{mcg} / \mathrm{ml}$ であり，0〜 4時間で阻止帯を示したるの 4 例, $4 \sim 8$ 時間で 4 例, $8 \sim 12$ 時間では 1 例であつ た。また1321 T Hでも14例中阻止带を示したもの はわずかに 3 例であり, 最高 $2.3 \mathrm{mcg} / \mathrm{ml}$ にすぎ なかつた。

丰験 7 ，喀痰中濃度と臨床効果

E B，KM，SMKついて，その喀痰中濃度と 臨床効果，とくに喀痰中結核菌の推移および耐性 出現との関係について検討した。

各薬物による治療の方法は，E Bについては E B未使用患者 22 例に E B 1 日 $1 \mathrm{~g} 1$ 回投与, $\mathrm{KM}$ はKM未使用患者23例にKM週 3〜4 g， S M S M既使用で SM感受性の患者29例に S M週 $2 \mathrm{~g}$ を6カ月間投与した。これらの症例について投与 前と 6 力月後の喀痰中結核菌の推移ならびに耐性 獲得状沉を観察した。耐性基準はとれぞれ E B 5 $\mathrm{mcg} / \mathrm{ml}$ 完全括よび不完全酎性，KM扣よび SMで は $10 \mathrm{mcg} / \mathrm{ml}$ 完全あるいは $10 \mathrm{mcg} / \mathrm{ml}$ 不完全, 100 
表 7, 喀痰中濃度と結核菌の推移おょび面性出聣状沉

\begin{tabular}{|c|c|c|c|c|c|c|c|c|}
\hline & \multirow{2}{*}{ 喀痰中蕧度 } & \multirow{2}{*}{$\begin{array}{l}\text { 例 } \\
\text { 数 }\end{array}$} & \multicolumn{3}{|c|}{ 喀嵌中結核菌推移 } & \multicolumn{3}{|c|}{ 耐性出現犾況 } \\
\hline & & & $\oplus-\Theta$ & $\oplus-\ominus-\oplus$ & $\oplus-\oplus$ & $\begin{array}{l}\text { 利性 } \\
\text { 出現 }\end{array}$ & $\begin{array}{l}\text { 篗性 } \\
\text { 繶 }\end{array}$ & 米判定 \\
\hline \multirow{3}{*}{ EB } & $\geqq 5 \mathrm{mcg} / \mathrm{ml}$ & 8 & 2 & 6 & & 2 & 1 & 3 \\
\hline & $2.5 \sim 4.9$ & 7 & 2 & 2 & 3 & 3 & 1 & 1 \\
\hline & $<2.5$ & 7 & 2 & 1 & 4 & 2 & 3 & 1 \\
\hline \multirow{4}{*}{$\mathrm{KM}$} & $\geq 10 \mathrm{mcg} / \mathrm{ml}$ & 5 & & & 5 & 3 & 1 & 1 \\
\hline & $5 \sim 9.9$ & 5 & 1 & 1 & 3 & 1 & 2 & 1 \\
\hline & $2 \sim 4.9$ & 9 & 1 & & 8 & 1 & 4 & 3 \\
\hline & $<2.0$ & 4 & & & 4 & 1 & 3 & \\
\hline \multirow{3}{*}{$\mathrm{SM}$} & $\geqq 4 \mathrm{mcg} / \mathrm{ml}$ & 6 & 1 & & 5 & 4 & 1 & \\
\hline & $2-3.9$ & 6 & 2 & 1 & 3 & 3 & 1 & \\
\hline & $<2,0$ & 17 & 2 & 6 & 9 & 4 & 10 & 1 \\
\hline
\end{tabular}

$\mathrm{mcg} / \mathrm{ml}$ 不完全耐性以上とした。

成績は表 7 に示すごとく，E B では喀痰中濃度 $5 \mathrm{mcg} / \mathrm{ml}$ 以上の 8 例中 2 例は 菌陰転持続 6 例は 一時的陰性化を認め，2.5〜 $5 \mathrm{mcg} / \mathrm{ml}$ の 7 例では 2 例陰転, 陽性持続は 3 例であり， $2.5 \mathrm{mcg} / \mathrm{ml}$ 以 下の 7 例では 4 例が菌陽性持続を示した。亦た而 性出現状況については $2.5 \mathrm{mcg} / \mathrm{ml}$ 以上のもので は判定しえたもの 7 例中 5 例に耐性出現を認めた のに対し，2.5 $\mathrm{mcg} / \mathrm{ml}$ 以下では 5 例中 2 例にすぎ なかつた，SMならびにKM使用例ではきわめて 菌陰転例が少なく，喀痰中結核菌の推移々喀痰中 濃度との間に相関は認めえなかつたが，KM耐性 出現では $5 \mathrm{mcg} / \mathrm{ml}$ 以上の 7 例中 4 例に 酎性獲得 が認められたのに対し，5 $\mathrm{mcg} / \mathrm{ml}$ 以下では 9 例 中 2 例であり, $\mathrm{SM}$ です $2 \mathrm{mcg} / \mathrm{ml}$ 以上の 9 例中 7 例に耐性出現が認められ，2.0 $\mathrm{mcg} / \mathrm{ml}$ 以下では 14例中10例が感性持続を示した。

\section{第 4 章 総括ならびに考案}

喀疢中の抗結核薬の湘定法は，血中あるいは尿 中濃度の測定法に比して, 種々の困難が伴ならの で，こ就にかれする報告は比較的少ない，生物的 測定を妨げる要因の主なるのは，雑菌による污染 および喀痰の不均質の問題であるう。このために 河盛”の提唱したパパイン液による消化および加 熱処理を用いたが，眮念された各薬物の力価の低
下はほとんどなく，前処理法としてこれが有用で あることを確認したので以下の実験にはすべて本 法を用いた。

喀痰中抗結核薬濃度の経時的推移については， 西川 ${ }^{6)}$ 子重層法を用いて KM $1 \mathrm{~g}$ 筋注後 6例につ き測定し，注射後 1 時間で 5.4〜20 $\mathrm{mcg} / \mathrm{ml}$ であ り，2 時間後が最高值を示し 平均 $25.1 \mathrm{mcg} / \mathrm{ml}$ あるが，その後減少して 5，6時間で測定不能の 低值になるるのが多く，12時間では全例測定不能 であつたと報告している，金沢》あ KM 1 g筋注 後12時間では測定不能であつたと述へ，望月 ${ }^{8)}$ 結核患者 5 例について S M $1 \mathrm{~g}$ 筋注後の喀痰中濃 度の推移は，2 時間後に最高となるすのが 4 例 でそれぞれ 2.3，1.8，0.7，0.6 $\mathrm{mcg} / \mathrm{ml}, 8$ 時間後では 3 例のみ測定しえたが，12時間後は全 例測定できなかつたと述へ，さらにI NH 200mg 経口投与後10例についての喀痰中 I NH濃度は 2 $\sim 4$ 時間後に最高值 $2.0 \sim 6.4 \mathrm{mcg} / \mathrm{ml}$ 示し, 12時間後では $0.5 \sim 1.9 \mathrm{mcg} / \mathrm{ml}$ であり，24時間 後でも全例測定可能であつて，血中濃度のほぼ $1 / 2$ 〜1/3であつたと報告している. 古沢9) む I NH $300 \mathrm{mg}$ 服用後 $10 \sim 12$ 時間後も 46 例中32例飞 $1 \sim 5$ $\mathrm{mcg} / \mathrm{ml}$ 程度認めたとし, 河村 ${ }^{2}$ は I N H 200mg経 口投与後の愘痰中濃度は血中濃度のほぼ $1 / 2 \sim 1 / 4$ で あると報告している。

わたくしは主としていわゆる二次抗結核薬の喀 疢中濃度について検討したのであるが，まず $\mathrm{E} \mathrm{B}$ については 9〜11時間蓄痰で 1.6〜 $4.4 \mathrm{mcg} / \mathrm{ml}$, 11〜13時間で2.1〜3.8 $\mathrm{mcg} / \mathrm{ml}, 13 \sim 15$ 時間の蓄痰 について検討した 2 例でも $2.1 \mathrm{mcg} / \mathrm{ml}$ 打よび 3.3 $\mathrm{mcg} / \mathrm{ml}$ 濃度を証明しえた。すなわち E B 投与 後の喀痰中濃度は望月, 古沢が I NHについて認 めた成績と似ている。一方 $\mathrm{E}$ B の血中濃度につい

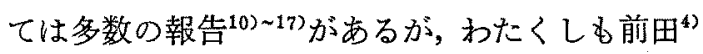
らと報告したごとく，E B $25 \mathrm{mg} / \mathrm{kg}$ 投与後は $2 \sim 4$ 時間に最高值を示すものが多く, 平均 $3.8 \mathrm{mcg} / \mathrm{ml}$ であつた。今回测定した E B 血中濃度もほぼ同様 の值を示し，8時間では $0 \sim 1.5 \mathrm{mcg} / \mathrm{ml}$ に低下す るにもかかわらず，喀痰中濃度が長時間にわたつ 
て測定でき，かつ血中濃度 4 時間値と同等の濃度 を認めることは，E B が喀痰中結核菌に対して発 育阻止濃度以上の濃度で作用することを示してい る.これに反して1321 T H，1314 T Hは血中濃度 も低值ではあつたが，4時間後には大多数の症例 に扣いて測定可能であつたのに対し，喀疢中濃度 はさらに低值で証明しえない例が多かつた。

次にC P Mの喀痰中濃度は $0 \sim 1$ 時間では27例 中18例が測定不能であり，1〜3時間では13例中 測定不能なるのは 1 例で最高 $17.3 \mathrm{mcg} / \mathrm{ml}, 3 \sim 5$ 時間では 全例 $4.4 \sim 18.7 \mathrm{mcg} / \mathrm{ml}$ の 範囲内にある が, $7 \sim 9$ 時間では14例中 7 例が測定不能の低值 を示し，1〜5時間をピークとして経時的に濑減 する傾向がらかがえた。またC P M ，KM， SM の喀痰中濃度を同一症例飞ついて比較すると, 個 々の症例では，濃度の高低は区々であるが，一般 KC P Mが最高值を示するのが多く，次いでKM， SMの順であつた.

次いで血中濃度, 肺組織内濃度と喀㾳中濃度の 関係を検討した。すなわちE B そついて肺組織内 濃度と血中濃度を 6 例の肺切除手術を行なつた症 例について測定したところ，6 例とも内服後 4 時 間以上経過しているが，健康部で 1.9 $8.2 \mathrm{mcg} /$ gの值を示し, 術前採血を行なつた 2 例では血中 濃度より高濃度の値を示した。このことは E Bの 喀痰中濃度が長時間, 相当な濃度で持続すること と相俟つて E B の肺組織親和性が高いことを思わ しめる. しかし空洞内では 2 例とも $0.6 \mathrm{mcg} / \mathrm{g}$ 以 下で健康部，空洞壁に比べて低值であつた。これ らは例数は少ないが金沢 ${ }^{153}$ ，馬場 ${ }^{14)}$ らの成績と一 致するものであつた。すなわち金沢は寒天平板拡 散法を用いて 1 日量 $1 \mathrm{~g}$ を経口 3 日間投与後の切 除肺の活性 E B 濃度を 4 例について測定し, 健康 部 $1.2 \sim 5.2 \mathrm{mcg} / \mathrm{ml}$, 空洞壁 $1.1 \sim 4.0 \mathrm{mcg} / \mathrm{ml}$, 空洞内では 0.6，0.6>であつたとしている。馬 場は肺切除患者36例に術前 E B 0.591 回内服さ せ肺切除之同時に採血 $儿$ ，肺組織内濃度（健康 部）と血中濃度を直立拡散法を用いて測定してい るが，36例中肺組織内濃度が高值を示すもの 11 例, 血中濃度が高いものは 1 例のみであり, とく にE B内服から切除まで 4 時間以上を要したもの
に肺組織内濃度が血中濃度より高値を示す例が多 かつたと述べている。

また金沢 ${ }^{15}$ はマウスにE Bを経口投与して各蔵 器内濃度を測定しているが，それによると腎>肺 >肝 脾の順となつている。わたくしも腎結核お

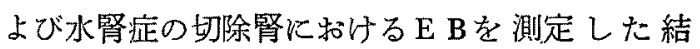
果, 投与後 $6 \sim 9$ 時間経過しているにるかかわら ず，健康部で 2.5 10.7 $\mathrm{mcg} / \mathrm{g}$ と高濃度の值を えた。このことは E B 排泄の大部分が腎よりなさ れる(15)ことから当然ではあろうが，腎組織への 親和性が強いことも考学られる。

May ${ }^{18}$ は半合成penicillinであるampicillinの喀 痰中濃度を測定しているが，それによると喀痰中 濃度は血中濃度括よび喀痰量とは一定の相関関係 はなく，喀痰が膿珄の場合には喀痰中濃度は高 く，粘液性の場合には低いことを指摘し，濃度と 喀痰性状との関係に重要な点を見出している.三 瀬 ${ }^{19)}$ もこの点にかんして, erythromycin, chloramphenicol, penicilln, tetracyclineの喀痰中濃度 を測定した実験で，膿性喀痰が粘液性喀痰より高 濃度であつたと報告している，わたくしの成績で

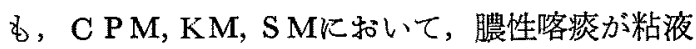
性のものよりかなり高濃度の值を示した。すなわ ち薬物が喀痰中に排泄される過程はMayらも指摘 するごとく単なる拡散ではなく，るつと能動的な ものではないかと考亲られ興味深い現象である。

喀痰中に含まれる抗結核薬の由来として, 気管 支を介して分泌されるるの，唾液より排泄される もの扣よび服用時口腔内に残存したものが混入す る場合とが考えられる。これにかんしてFrühlinger $^{20)}$ はP A S を服用させてから直後执よび 30 分 ごとに喀痰を採取しその中のPAＳが次第に減少 してくることから，口腔内に残存したPA S が混 入するためであるらとし，望月 ${ }^{8)}$ D A S 特よび I NH服用後含嗽せしめたものと，含嗽を行わな かつたものとの揢痰中濃度を測定し，含嗽を行な わなかつたものでは服用後 1 時間ころまで高濃度 であること，服用啳の含濑液に相当量のPA S 認めることなどから薬物の口腔内での混入を考慮 すべきことを述べている．古沢量はＩNHおよび PA S を経口投与した場合より静脈内投与の場合 
に喀痰中濃度は高く，排泪の遅延をみたことから 病巣周围および気管支から分泌されるものが喀痰 に排泄されるとしている，わたくしの成緼でる $\mathrm{E}$ $\mathrm{B}$ 喀痰中濃度測定の場合, 錠剂使用例とカプセル 使用例では 0 1 時間蓄痰の濃度に大さな差異が みられて括り，これは口腔内でのE B 混入が考え られ，喀疢中の結核菌検索については考慮さるべ きであろうと思う。

最後に喀痰中濃度と臨床効果については，喀痰 中結核菌の推移扣よび面性出現とを指標として検 討したが，E Bでは喀痰中䟴度 $2.5 \mathrm{mcg} / \mathrm{ml}$ 以上 の15例で菌陰転 4 例，一時的菌陰転 8 例，菌陽性 持続 3 例であつたのに 対し， $2.5 \mathrm{mcg} / \mathrm{ml}$ 以下 の 7 例では菌陽性持続 4 例を示した，耐性出現では $2.5 \mathrm{mcg} / \mathrm{ml}$ 以上では 7 例中 5 例, $2.5 \mathrm{mcg} / \mathrm{ml}$ 以 下では 5 例中 2 例に耐性を認めた。一方 $\mathrm{KM}$ 和よ び S Mではその喀痰中濃度と結核菌の推移には相 関性は認めえなかつたが，耐性出現については， $\mathrm{KM}$ では $5 \mathrm{mcg} / \mathrm{ml}$ 以上の 7 例中 4 例, $5 \mathrm{mcg} / \mathrm{ml}$ 以下の 9 例中 2 例に, $\mathrm{SM}$ では $2.0 \mathrm{mcg} / \mathrm{ml}$ 以上 の 9 例中 7 例， $2.0 \mathrm{mcg} / \mathrm{ml}$ 以下の 14 例中 4 例に耐 性出現を認め，喀痰中濃度の高いものに耐性出現 が速い傾向がうかがわれた。

肺結核に括ける喀痰中結核菌の陰性化，而性獲 得については種々な因子が関与するであるらが， 薬物と菌との接触が最も重要な因子であることは 論をまたないことであるう，E B，KM拈よびS Mに蛙いて喀痰中濃度が高いわのに菌の陰性化ま たは耐性出現が速い傾向が認められたことは，喀 痰中濃度が高いもの程，臨床的に病巣内でも結核 菌と薬物との接触が大きいことを示していると思 われる。このことから，抗結核薬を使用するにめ たつて，喀痰中濃度を測定することは，薬物の病 巣内への到達を知り，臨床効果を推定するために 有用なことであるうと推論したい。

\section{摘要}

パパイン液による喀痰の消化ならびに寒天平板 拡散法招よび直立拆散法により，抗結核㭗の喀痰 中濃度を測定しうることを確かめ，E B，C P M, KM， S M，1314 T H执よび1321 T Hの喀疢中濃 度および E B の肺扰よび腎組織内濃度を測定し，
併せて血中濃度との比較検討を行なつた。

1）E B 喀痰中濃度 は大多数 $1 \sim 5 \mathrm{mcg} / \mathrm{ml}$ の 範团内にあり，13〜15時間の蓄痰でも測定可能で あつた。また血中濃度 4 時間值とほぼ同等の值の 濃度を示したが，個々の症例では両者の相関性は 示さなかつた。

2）E B の肺組織掞よび腎組織中濃度はかなり の高濃度に証明できたが，空洞内では，健康部， 空洞壁に比し低值であつた。

3） C P Mの喀痰中濃度は血中濃度 1 時間值に 比し低濃度であつたが，汪とんど $3 \mathrm{mcg} / \mathrm{ml}$ 以上 にあり最高 $25.3 \mathrm{mcg} / \mathrm{ml}$ を示し， $1 〜 5$ 時間をピ 一クとして漸減する傾向にあつた。

4） C PM，KMおでび S Mの喀痰中濃度を比 較すると C PM>KM>SMの順であり， 3 薬と 屯膿性喀痰に扣いて粘液性喀痰より高濃度の值を 示寸ものが多からた。

5）1314 T Hおよび1321 T Hの喀痰中濃度はほ とんどの症例において測定不能の低值であつた．

6）E B，KMおよび S Mの喀痰中濃度と喀痰 中結核菌の推移および耐性出現状況を比較する と, 喀疢中濃度の高いものに喀痰中結核菌の陰性 化をたは耐性出現が速い傾向がうかがえた。

$$
\text { 文献 }
$$

1）河盛勇造 他：日本医事新報，25:1790，1958, -2）河村正一：日内会誌，47：1344，1958，一3) 金沢裕, 合又利夫：呼吸器診窥, $16: 681,1961$ 。 一4）前田徽 他: Chemotherapy, $13: 105 ， 1965$. 一5) 小川政敏：日本臨床結核, $16: 417,1957$. 6）西川政美：日本胸部疾患学会雑誌， $2: 311$, 1965. -7) 金沢裕他：J. Antibiotics ser. B. 13: $296,1960$. - -8) 望月靖三郎 : 名古屋医学, 80 : 1024, 1959. - - 9) 古沢久喜：名古屋医学, 73: 912, 1957. -10) Thomas, J. P., et al : Amer. Rev. Resp. Dis., 83, 891, 1961. - 11) Place, V.A. and Thomas, J.P.: Amer. Rev. Resp. Dis., $87,901,1963 .-12)$ 山本和男他: 日本胸部臨床, 22 : 797, 1963, -13) 五味二郎他: 日本胸部䠛床, $23: 77,1963$, -14）馬場洽賢他：日本胸部臨床, 23 : 862, 1964. -15) Kanazawa, Y. and Kuramata, T.: Chemotherapy. $12: 117,1965 .-16)$ Peet, E.A. et al : Amer. Rev. Resp. Dis., $91: 51$, 1965。一-17) 堂野前䌖摩郷他: 日本胸部䠛床，25： 912, 1966. -18) May, J.R et al : Lancet: 929 , 1965. - 19) 三瀬貞博 : Chemotherapy., $14: 31$, 1966. - 20) Frühlinger, B, et al : Amer. Rev. Tuberc., $68: 42,1953$. 